ISSN 2087-3336 (Print) | 2721-4729 (Online)

TEKNOSAINS: Jurnal Sains, Teknologi dan Informatika

Volume 9, Nomor 1, Januari 2022, hlm 29-39

http://jurnal.sttmcileungsi.ac.id/index.php/tekno

DOI: 10.37373

\title{
Analisis Pengaruh Jumlah Lubang Nozzle Injektor terhadap Torsi pada Pembesaran Piston Motor Matic Injection
}

\section{Analysis of the Influence of the Number of Injector Nozzle Holes on Torque on Matic Injection Motor Piston Enlargement}

\author{
Aprian Fadhlu Rahman ${ }^{1}$, Armila ${ }^{2 *}$, Rudi Kurniawan Arief ${ }^{3}$ \\ 1,2*,3 Program Studi Teknik Mesin, Fakultas Teknik, Universitas Muhammadiyah Sumatera Barat, Indonesia \\ 26181 \\ 1,2*,3 Jl. By Pass Aur Kuning No. 1 Bukittinggi, Sumatera Barat, Indonesia 26181 \\ *Koresponden Email: kimmylala74@gmail.com
}

Artikel dikirim: 9/9/2021

Artikel direvisi: 23/11/2021

Artikel diterima: 9/12/2021

\begin{abstract}
ABSTRAK
Sistem injeksi merupakan teknologi yang dapat meningkatkan performa mesin dan efisiensi bahan bakar. Teknologi injeksi bahan bakar (Fuel Injection System) adalah teknologi yang mencampur bahan bakar dengan udara sebelum masuk ke ruang bakar, kemudian disemprotkan dengan tekanan tertentu. Nozzle injektor berperan penting dalam penyemprotan bahan bakar. Terdapat lubang pada ujung nozzle, lubang ini merupakan sarana untuk menginjeksi bahan bakar dengan cara pengabutan. Penelitian ini dimaksudkan untuk mengetahui perubahan torsi dan daya pada sepeda motor honda Beat FI tahun 2014 dengan pembesaran piston 0,75 mm pada jumlah lubang nozzle injektor dengan variasi lubang 4. 6 dan 8 dengan bahan bakar pertamax. Alat yang dilakukan untuk pengujian ini adalah dynotest. Pada penelitian ini didapatkan data berupa kurva dari nilai torsi dan daya pada masing-masing lubang nozzle injektor. Hasil dari penelitian ini mendapatkan torsi dan daya tertinggi pada nozzle injektor lubang 4 dengan torsi maksimum sebesar 6,95 ft-lbs dan daya maksimum sebesar 8,75 HP pada putaran mesin $6.610 \mathrm{rpm}$. Pada nozzle injektor lubang 6 didapatkan torsi maksimum sebesar $6,82 \mathrm{ft}-\mathrm{lbs}$ dan daya maksimum sebesar 8,31 HP pada putaran mesin $6.400 \mathrm{rpm}$, sedangkan pada injektor lubang 8 didapatkan torsi maksimum sebesar 5,94 ft-lbs dan daya maksimum sebesar 7,14 HP pada putaran mesin $6.310 \mathrm{rpm}$.
\end{abstract}

Kata kunci: Nozzle, Injektor, Piston, Pembesaran, Dynotest

\section{ABSTRACT}

The injection system is a technology that can improve engine performance and fuel efficiency. Fuel injection technology (Fuel Injection System) is a technology that mixes fuel with air before it enters the combustion chamber, then is sprayed with a certain pressure. The injector nozzle plays an important role in fuel spraying. There is a hole at the end of the nozzle, this hole is a means for injecting fuel by atomizing. This study was intended to determine changes in torque and power on a 2014 Honda Beat FI motorcycle with a piston enlargement of $0.75 \mathrm{~mm}$ in the number of injector nozzle holes with variations of holes 4. 6 and 8 with Pertamax fuel. The tool used for this test is the dynotest. In this study, data obtained in the form of curves of the torque and power values for each injector nozzle hole. The results of this study get the highest torque and power at the 4 hole injector nozzle with a maximum torque of $6.95 \mathrm{ft}$-lbs and a maximum power of $8.75 \mathrm{HP}$ at 6,610 rpm engine speed. In the 6 hole injector nozzle, the maximum torque is $6.82 \mathrm{ft}-\mathrm{lbs}$ and the maximum power is $8.31 \mathrm{HP}$ at 6,400 rpm engine speed, 
while the 8 hole injector has a maximum torque of $5.94 \mathrm{ft}$-lbs and the maximum power is $7,14 \mathrm{HP}$ at 6,310 rpm. engine speed.

Keywords: Injector, Nozzle, Piston, Enlargement, Dyno test.

\section{PENDAHULUAN}

Sistem injeksi merupakan teknologi yang dapat meningkatkan performa mesin dan efisiensi bahan bakar. Sistem injeksi pada sepeda motor dapat menghasilkan kendaraan yang hemat bahan bakar sekaligus ramah lingkungan[1]. Teknologi injeksi bahan bakar (Fuel Injection System) adalah teknologi yang mencampur bahan bakar dengan udara sebelum masuk ke ruang bakar, kemudian disemprotkan dengan tekanan tertentu. Sistem ini menggunakan beberapa sensor untuk mengukur jumlah bahan bakar dan mengatur waktu penyemprotan yang benar. Komponen penting dalam sistem injeksi bahan bakar adalah injektor[2]. Nozzle injektor berperan sebagai penyemprot bahan bakar ke saluran masuk (intake manifold)[3]. Terdapat beberapa lubang-lubang kecil pada ujung nozzle, lubang ini merupakan sarana untuk menginjeksi bahan bakar dengan cara pengabutan. Efisiensi injeksi bahan bakar dipengaruhi oleh banyak parameter yaitu tekanan injeksi, akurasi bahan bakar, tekanan udara, dan jumlah lubang nozzle injektor.

Penelitian terdahulu yang melakukan pengujian dengan spesifikasi motor Beat FI standar dengan variasi lubang nozzle 4, 6 dan 8. Menggunakan pertalite Ron 90. Hasil penelitian menunjukkan pada nozzle lubang 6 memiliki daya dan torsi tertinggi yang menghasilkan daya maksimum sebesar 7,42 HP pada putaran $6500 \mathrm{rpm}$ dan torsi maksimum sebesar 5,89 ft-lbs pada putaran mesin $6500 \mathrm{RPM}[2]$. Sedangkan pada penelitian ini dilakukan dengan motor beat FI tahun 2014 yang telah dilakukan pembesaran piston $0,75 \mathrm{~mm}$ menggunakan bahan bakar pertamax.

Objek penelitian adalah sepeda motor Beat FI tahun 2014 dengan pembesaran diameter piston 0,75 $\mathrm{mm}$ dan bahan bakar yang digunakan adalah pertamax. Jumlah lubang nozzle injektor yang digunakan pada pengujian ini antara lain lubang 4, lubang 6 (bawaan pabrik), dan lubang 8. Pengujian ini dilakukan menggunakan dynotest [4][5].

Motor bakar 4 langkah adalah mesin yang dalam satu kali siklus pembakaran terdapat empat langkah piston. Proses kerja motor bakar empat langkah dimulai dengan langkah induksi atau langkah hisap, yaitu proses tekanan konstan, kemudian dilanjutkan dengan proses kompresi, di mana campuran bahan bakar dan udara dimampatkan. Tekanan yang dihasilkan oleh pembakaran bekerja pada piston sehingga menyebabkan piston bergerak[6]. Tenaga gerak inilah yang digunakan untuk menggerakkan motor. Gerakan piston yang bergerak naik turun akan diubah oleh poros engkol menjadi gerak rotasi. Langkah buang merupakan proses terakhir dari sepeda motor bakar empat langkah. Gas yang dihasilkan dari pembakaran dibuang melalui knalpot[7][8][9].

Mesin dua langkah adalah mesin pembakaran dalam yang membutuhkan dua langkah kerja dalam proses pembakaran didalam silinder. Dibandingkan dengan motor bakar empat langkah, struktur sepeda motor dua tak sangatlah sederhana. Dalam motor dua langkah, untuk mewujudkan siklus kerja, diperlukan dua langkah gerakan piston atau satu putaran poros engkol. Siklus adalah rangkaian peristiwa yang selalu berulang dan membentuk lingkaran tertutup mengikuti lintasan yang sama seperti sebelumnya. Struktur motor dua langkah relatif sederhana, dan pembukaan dan penutupan saluran masuk dan keluar semuanya diselesaikan oleh piston itu sendiri. Oleh karena itu, berat per satuan daya yang dihasilkan kecil[10][11].

Sistem bahan bakar berfungsi menyediakan bahan bakar bertekanan tinggi $(2,5-3 \mathrm{Kg} / \mathrm{cm} 2)$. Komponen-komponen yang terdapat pada sistem bahan bakar EFI sepeda motor[12] sesuai dengan gambar 1.

a. Fuel tank 
Fuel tank atau tangki bensin terbuat dari lembaran baja tipis yang terletak di bagian belakang kendaraan untuk mencegah terjadinya kebocoran apabila terjadi benturan.

b. Fuel suction filter.

Fuel suction filter atau saringan bahan bakar berperan untuk menyaring kotoran ataupun air yang mungkin terdapat pada bensin.

c. Fuel injector.

Fuel injector berfungsi untuk menginjeksikan bahan bakar agar bahan bakar berbentuk butiranbutiran lembut.

d. Fuel pump

Pompa bensin yang biasa digunakan pada kendaraan dengan sistem EFI adalah pompa bensin electric yang berperan untuk menghisap bahan bakar dari tangki kemudian menyalurkan ke sistem bahan bakar.

e. Throttle body.

Sistem induksi udara berfungsi mengatur dan mengukur aliran udara yang masuk ke dalam silinder[7].

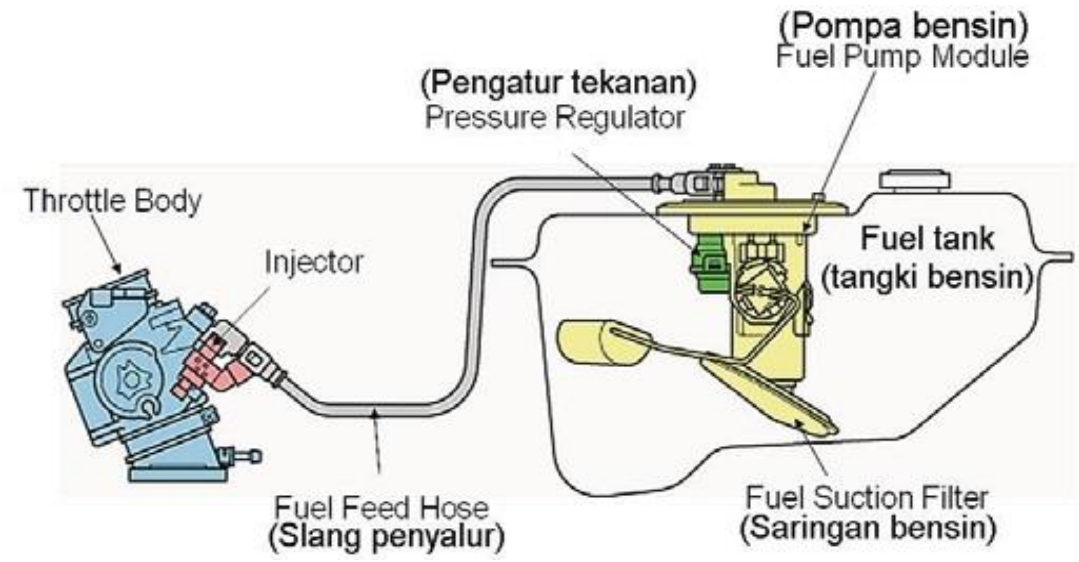

Gambar 1. Komponen sistem bahan bakar EFI

A. Nozzle Injector

Nozzle injector berperan untuk menyemprotkan bahan bakar menuju mesin untuk dicampur dengan udara, supaya bahan bakar dapat bercampur dengan udara maka bensin dikabutkan dengan halus sehingga berganti jadi uap[13]. Sistem EFI dapat menciptakan campuran udara serta bahan bakar yang pas sebab disesuaikan dengan jumlah serta temperatur udara yang masuk, kecepatan mesin, temperatur air pendingin, posisi throttle, posisi crankshaft, serta keadaan berarti yang lain[14][15][16].

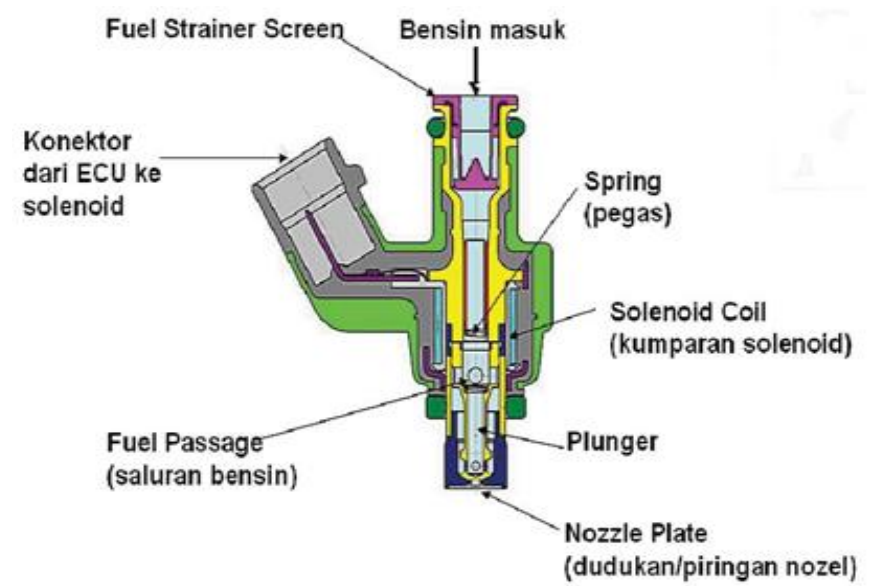

Gambar 2. Komponen injektor 
Analisis Pengaruh Jumlah Lubang Nozzle Injektor terhadap Torsi pada Pembesaran

Piston Motor Matic Injection

Injektor bekerja dengan cara yang sama seperti alat suntik, dengan bagian yang bergerak naik turun disebut plunger. Terdapat jarum di ujung plunger untuk menutup lubang nozzle saat tidak bekerja. Ketika injector diberi energi, plunger tertarik dan jarum diangkat, sehingga bensin yang berada pada injector akan menyemprot ke luar sebab ditekan oleh pompa bahan bakar yang berada di dalam tangki bahan bakar. Ketika coil solenoid menerima sinyal dari ECU, plunger ditarik oleh tegangan pegas. Needle valve dan plunger adalah satu kesatuan, sehingga valve juga ditarik keluar dari dudukan dan bahan bakar akan diinjeksikan melalui ujung injector. Pengaturan volume injeksi bahan bakar sesuai dengan durasi sinyal, sementara langkah needle valve tetap tidak berubah[3].

\section{METODE}

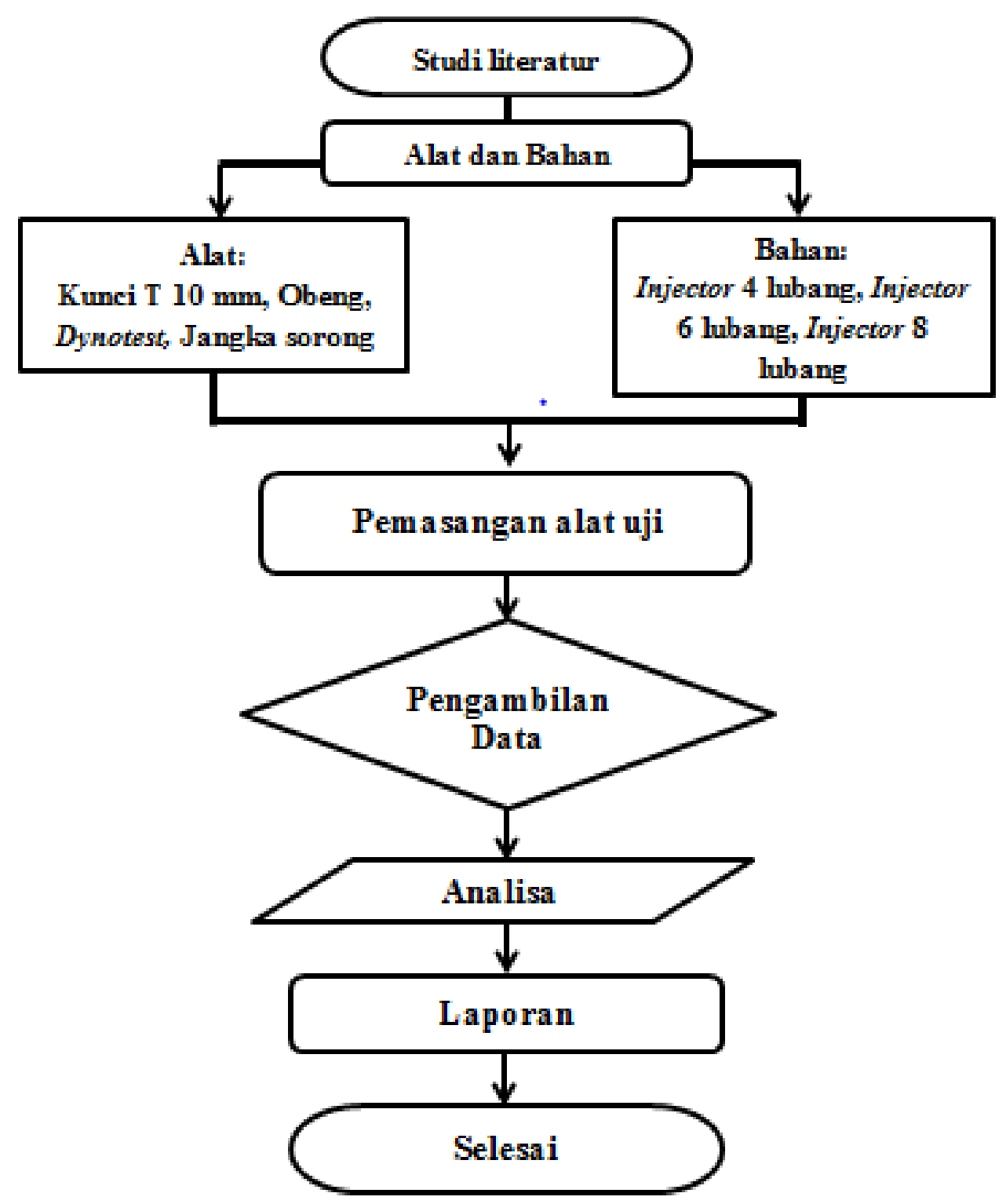

Gambar 3. Diagram Alir

2.1 Alat-alat penelitian

a. Kunci T $10 \mathrm{~mm}$

b. Obeng 
c. Jangka sorong

Jangka sorong digunakan untuk mengukur diameter lubang nozzle injektor dengan jarum sebagai alat bantu dalam pengukuran dengan cara menusukkan jarum pada lubang injektor[17]. Pada gambar 4 menggunakan jarum sebagai alat bantu pengukuran.

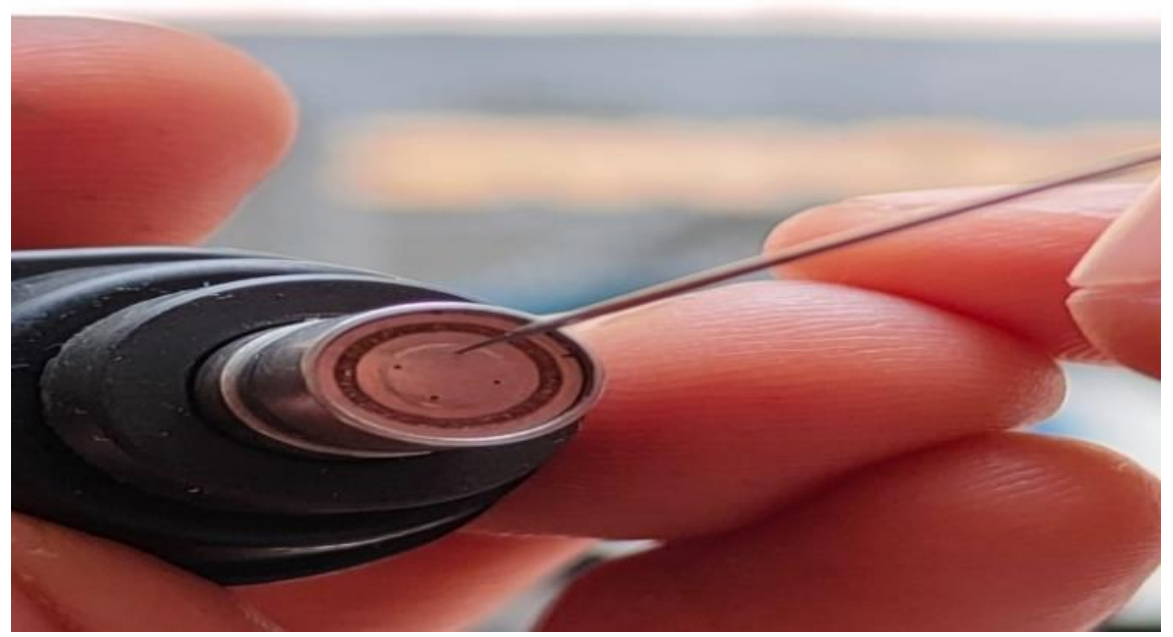

Gambar 4. Pengukuran lubang menggunakan jarum

Kemudian jarum tersebut diukur menggunakan jangka sorong untuk mengetahui besar diameter pada lubang injektor. Gambar 5 pengukuran menggunakan jangka sorong.

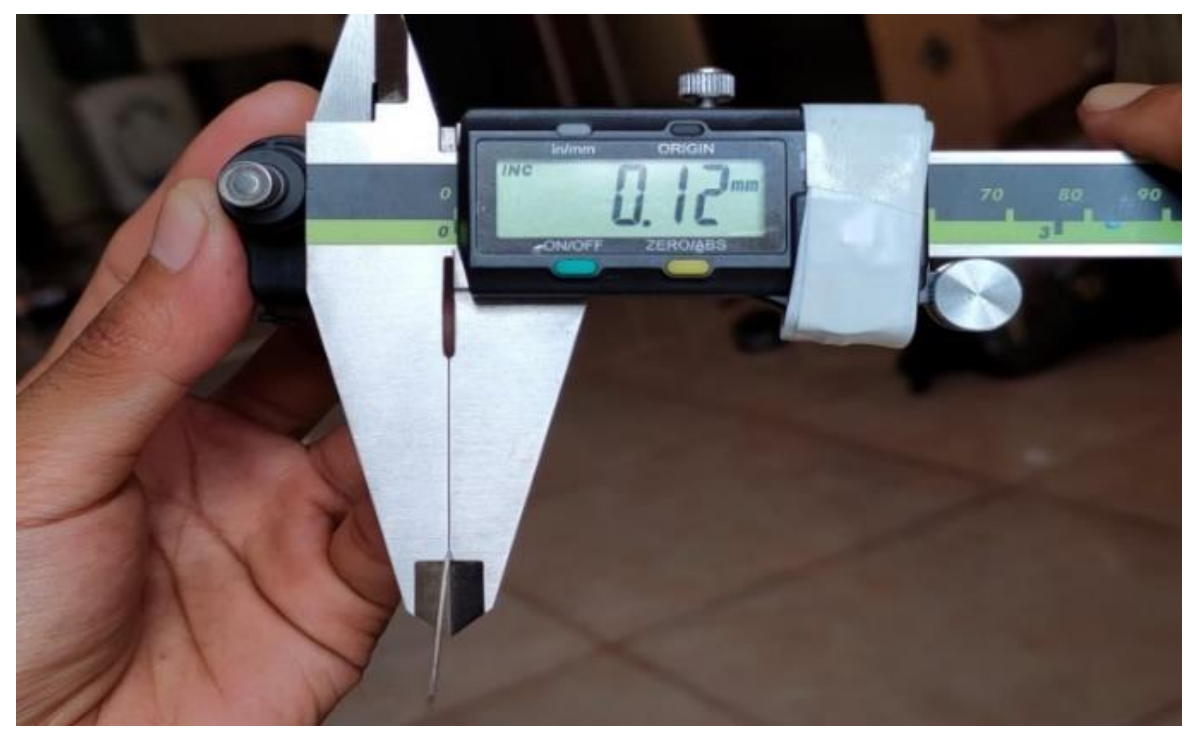

Gambar 5. Pengukuran menggunakan jangka sorong

Pada masing-masing injektor dilakukan metode pengukuran yang sama untuk mengetahui besar diameter pada lubang injektor. Hasil dari pengukuran didapatkan besar diameter lubang injektor 0,12 mm pada injektor lubang 4, 6 dan 8 .

\section{d. Dynotest}

Pengujian dilakukan menggunakan dynotest untuk mendapatkan torsi dan daya sepeda motor pada beberapa putaran mesin. 
Analisis Pengaruh Jumlah Lubang Nozzle Injektor terhadap Torsi pada Pembesaran

Piston Motor Matic Injection

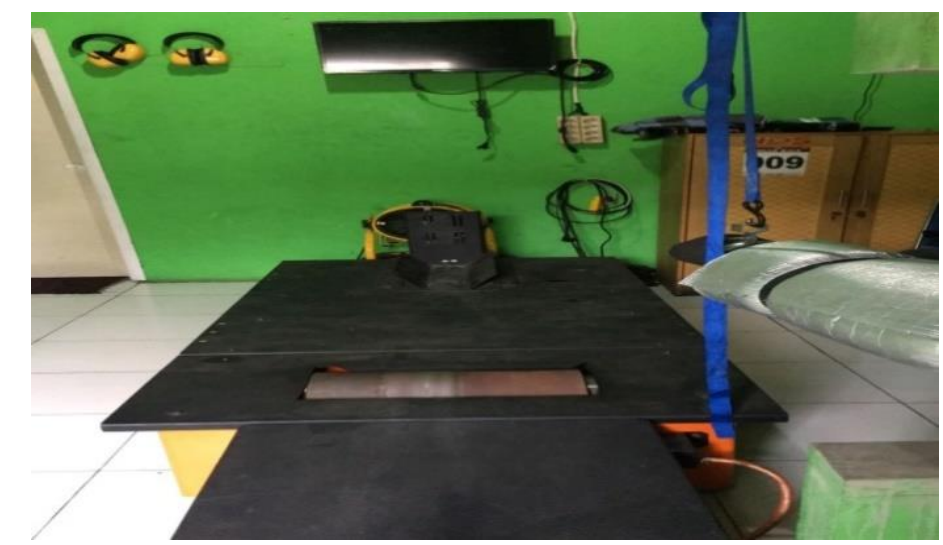

Gambar 6. Dynotest

Pada dynotest terdapat monitor yang menunjukkan nilai torsi dan daya yang didapatkan setelah melakukan running test.

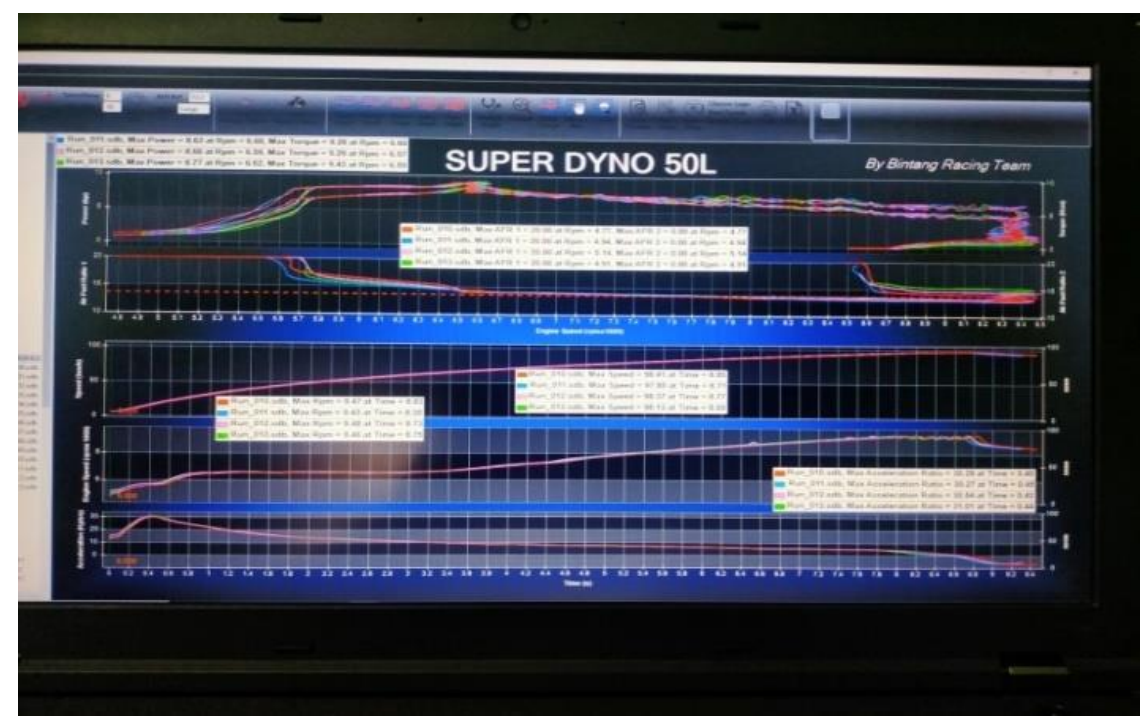

Gambar 7. Monitor dynotest

2.2 Bahan-bahan penelitian

a. Injektor lubang 4

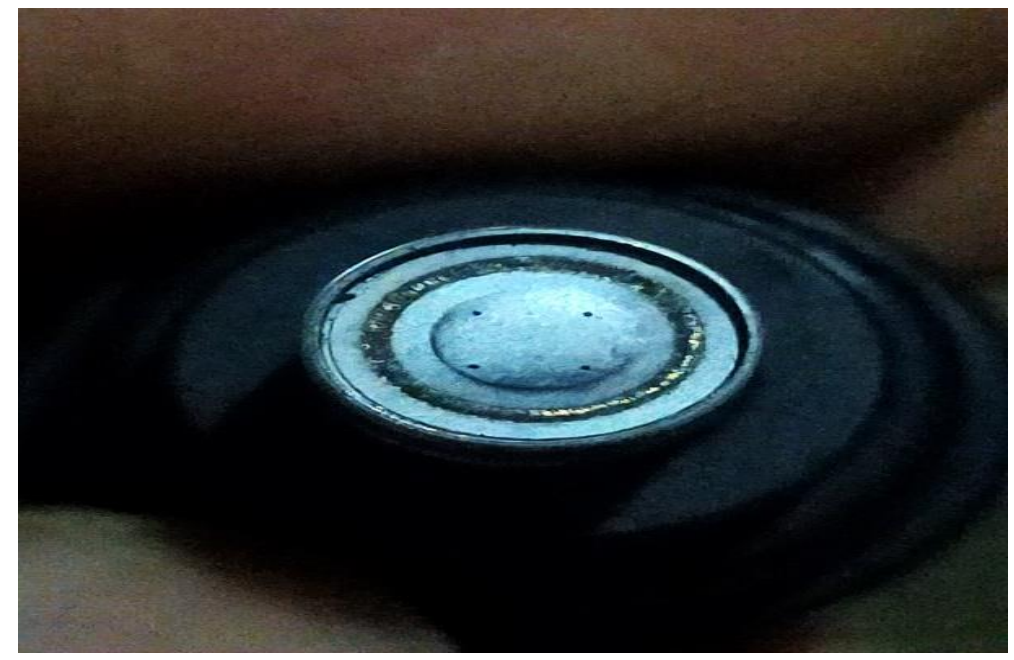

Gambar 8. Nozzle injektor lubang 4 
Dapat dilihat pada gambar 8. terdapat nozzle injector yang lubangnya berjumlah 4 .

b. Injektor lubang 6

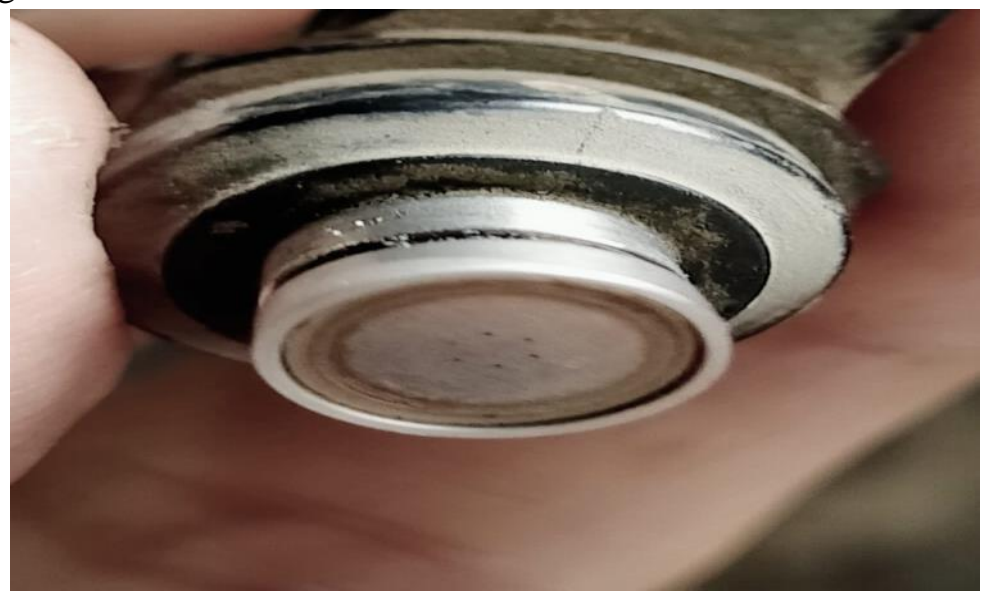

Gambar 9. Nozzle injektor lubang 6

Dapat dilihat pada gambar 9. terdapat nozzle injector yang lubangnya berjumlah 6 (standar bawaan pabrik).

c. Injektor lubang 8

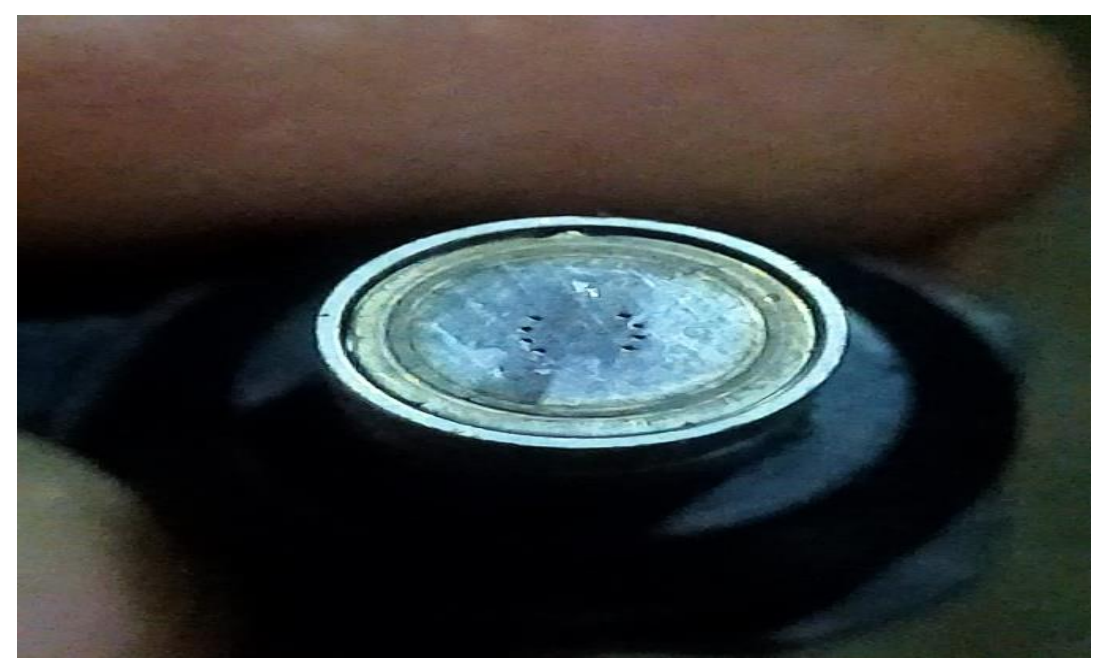

Gambar 10. Nozzle injektor lubang 8

Dapat dilihat pada gambar 10. terdapat nozzle injektor yang lubangnya berjumlah 8 .

\subsection{Waktu dan tempat pengujian}

Pengujian dilakukan pada bulan Juni sampai bulan Juli 2021, tempat pengujian yaitu di teklek speed shop Jl. Jembatan Tamsis No 43, Jati, Kota Padang, Sumatera Barat 25171, Padang, Indonesia 25171.

\subsection{Langkah-langkah pengambilan data}

a. Mempersiapkan semua alat dan bahan yang diperlukan untuk pengujian torsi dan daya pada sepeda motor.

b. Melakukan pengecekan pada oli supaya tidak terjadi overheat saat melakukan pengujian.

c. Memasang injektor pada sepeda motor yang dimulai dari injektor lubang 4, 6, dan 8 secara berurutan.

d. Menaikkan sepeda motor ke atas dynotest. 
Analisis Pengaruh Jumlah Lubang Nozzle Injektor terhadap Torsi pada Pembesaran

Piston Motor Matic Injection

e. Menghidupkan mesin untuk mendapatkan putaran mesin yang stabil sebelum melakukan pengujian.

f. Melakukan running test dengan menggunakan injektor lubang 4, 6, dan 8 dari putaran mesin terendah sampai putaran mesin tertinggi dengan menarik gas secara penuh untuk mendapatkan data berupa torsi dan daya.

g. Melakukan pengujian pada masing-masing injektor sebanyak 5 kali running test untuk mendapatkan data torsi dan daya yang lebih akurat. Data yang didapatkan pada pengujian akan langsung direkam oleh komputer dalam bentuk kurva.

\section{HASIL DAN PEMBAHASAN}

3.1 Analisis torsi

Berikut data yang didapatkan berupa nilai torsi pada injektor lubang 4,6 dan 8 terhadap beberapa putaran mesin.

Tabel 1. Data pengujian torsi berdasarkan putaran mesin

\begin{tabular}{cccc}
\hline $\begin{array}{c}\text { Putaran mesin } \\
(\mathrm{rpm})\end{array}$ & \multicolumn{3}{c}{ Torsi (ft-lbs) } \\
\cline { 2 - 4 } & Injektor Lubang 4 & Injektor Lubang 6 & Injektor lubang 8 \\
\hline 5.200 & 1,43 & 1,28 & 2,33 \\
5.500 & 2,53 & 2,62 & 5,09 \\
6.000 & 6,23 & 5,84 & 5,48 \\
6.310 & 6,32 & 5,92 & 5,94 \\
6.400 & 6,38 & 6,82 & 5,55 \\
6.610 & 6,95 & 5,91 & 5,2 \\
7.000 & 5,66 & 5,56 & 4,97 \\
7.500 & 5,06 & 4,97 & 4,28 \\
8.000 & 4,9 & 4,55 & 4,11 \\
8.500 & 4,39 & 4,08 & 2,06 \\
9.000 & 3,72 & 3,71 & 1,54 \\
\hline
\end{tabular}

Berikut Grafik yang menjelaskan perubahan torsi yang didapatkan berdasarkan beberapa putaran mesin pada injektor lubang 4, 6 dan 8 .

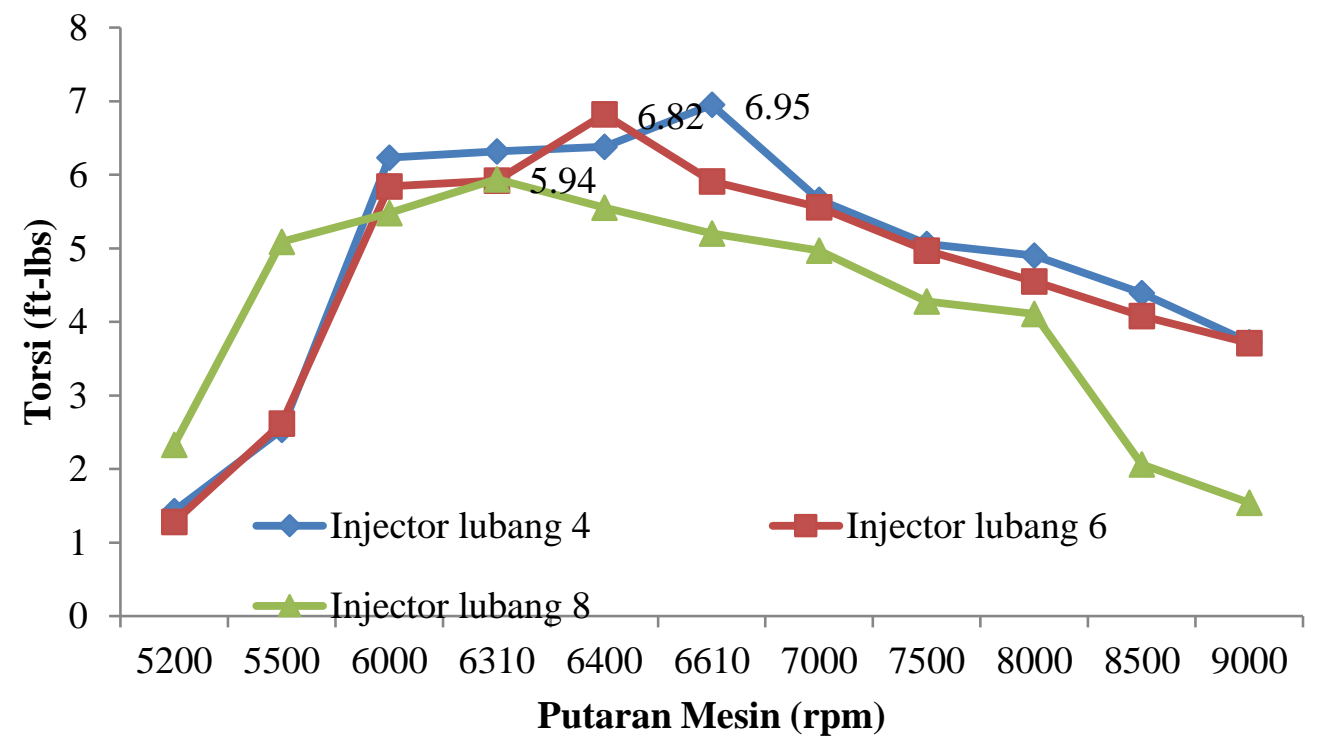

Gambar 11. Grafik hubungan torsi dengan putaran mesin 
Dari grafik pada gambar 11. Di atas dapat dilihat torsi tertinggi terdapat pada injektor lubang 4 dengan torsi maksimum sebesar $6,95 \mathrm{ft}-\mathrm{lbs}$ pada putaran mesin $6.610 \mathrm{rpm}$, dan pada injektor lubang 6 didapatkan torsi maksimum sebesar $6,82 \mathrm{ft}-\mathrm{lbs}$ pada putaran mesin $6.400 \mathrm{rpm}$, sedangkan pada injektor lubang 8 didapatkan torsi maksimum sebesar 5,94 ft-lbs pada putaran mesin $6.310 \mathrm{rpm}$.

3.2 Analisis daya

Berikut data yang didapatkan berupa nilai daya pada injektor lubang 4,6 dan 8 terhadap beberapa putaran mesin.

Tabel 2. Data pengujian daya berdasarkan putaran mesin

\begin{tabular}{cccc}
\hline \multirow{2}{*}{$\begin{array}{c}\text { Putaran mesin } \\
(\mathrm{rpm})\end{array}$} & \multicolumn{3}{c}{ Daya (HP) } \\
\cline { 2 - 4 } & Injektor Lubang 4 & Injektor Lubang 6 & Injektor lubang 8 \\
\hline 5.200 & 1,44 & 1,28 & 2,33 \\
5.500 & 2,65 & 2,75 & 5,33 \\
6.000 & 7,11 & 6,67 & 6,26 \\
6.310 & 7,58 & 7,12 & 7,14 \\
6.400 & 7,78 & 8,31 & 6,76 \\
6.610 & 8,75 & 7,43 & 6,54 \\
7.000 & 7,54 & 7,41 & 6,62 \\
7.500 & 7,22 & 7,11 & 6,11 \\
8.000 & 7,47 & 6,93 & 6,25 \\
8.500 & 7,1 & 6,6 & 3,37 \\
9.000 & 6,38 & 6,36 & 2,64 \\
\hline
\end{tabular}

Berikut Grafik yang menjelaskan perubahan daya yang didapatkan berdasarkan beberapa putaran mesin pada injektor lubang 4, 6 dan 8 .

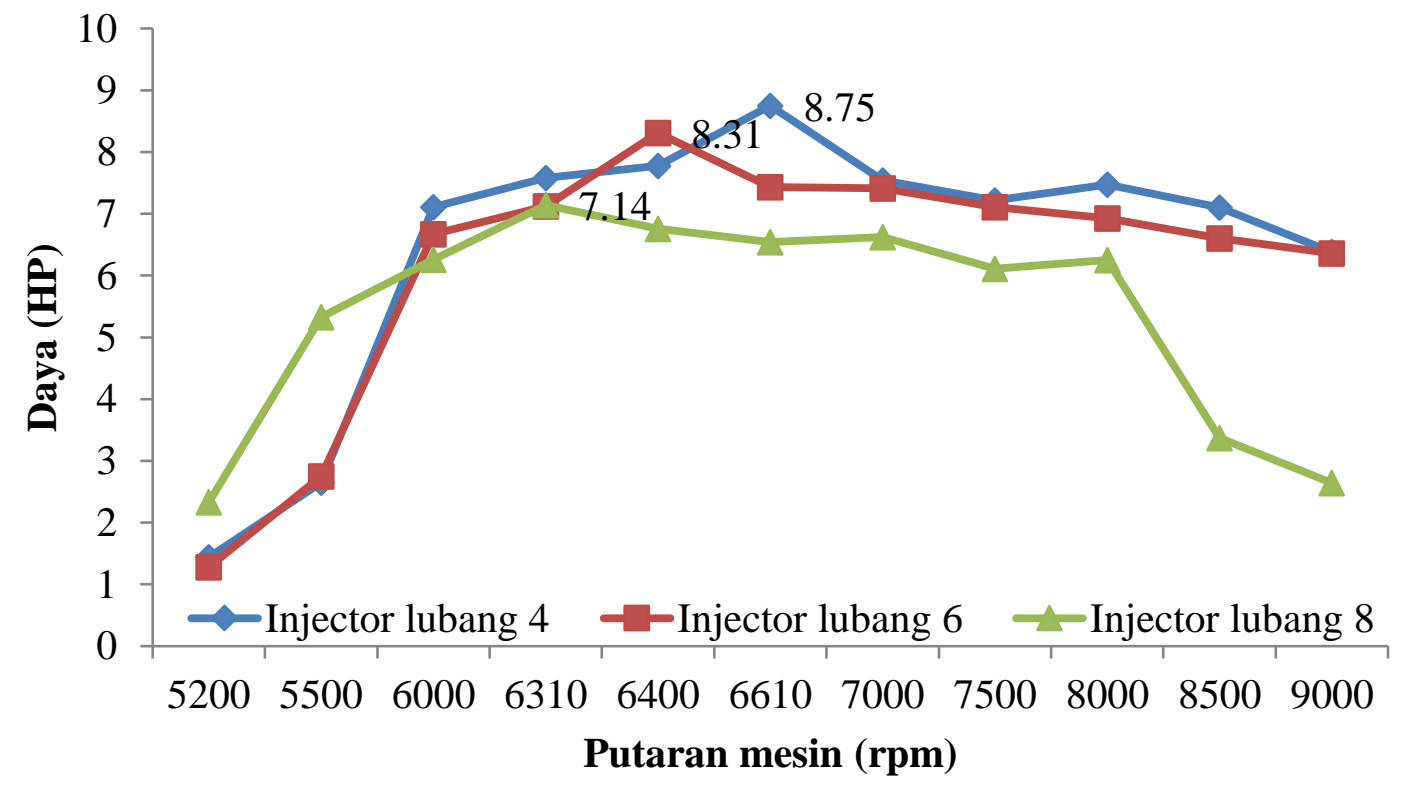

Gambar 12. Grafik hubungan daya pada putaran mesin

Dari grafik pada gambar 12. bisa dilihat daya tertinggi terdapat pada injektor lubang 4 dengan daya maksimum sebesar 8,75 HP pada putaran mesin $6.610 \mathrm{rpm}$, dan pada injektor lubang 6 didapatkan daya maksimum sebesar $8,31 \mathrm{HP}$ pada putaran mesin $6.400 \mathrm{rpm}$, sedangkan pada injektor lubang 8 didapatkan daya maksimum sebesar 7,14 HP pada putaran mesin $6.310 \mathrm{rpm}$. 
Analisis Pengaruh Jumlah Lubang Nozzle Injektor terhadap Torsi pada Pembesaran

Piston Motor Matic Injection

\section{SIMPULAN}

Berdasarkan penelitian pada masing-masing lubang nozzle injektor didapatkan torsi dan daya tertinggi pada nozzle injektor lubang 4 dengan torsi maksimum sebesar $6,95 \mathrm{ft}-\mathrm{lbs}$ pada putaran mesin $6.610 \mathrm{rpm}$ dan daya maksimum sebesar $8,75 \mathrm{HP}$ pada putaran mesin $6.610 \mathrm{rpm}$ pada pembesaran piston $0,75 \mathrm{~mm}$. Maka nozzle injektor yang sesuai untuk diaplikasikan yaitu nozzle injektor lubang 4 .

\section{REFERENSI}

[1] V. Tristianto, "Pengaruh Penggunaan Injector Vixion Dan Ecu Racing," no. 2, pp. 1-10, 2016.

[2] M. V. Hermawan and A. E. Winarta, "Studi Eksperimen Pengaruh Jumlah Lubang Nosel Injektor Terhadap Performa Mesin Sepeda Motor," J. Tek. Atw, no. 23, pp. 77-84, 2020.

[3] R. Kurniawan, "Analisis Pengaruh Penggunaan Injector Terhadap Unjuk Kerja Honda Beat Fi," Anal. Pengaruh Pengguna. Inject. Terhadap Unjuk Kerja Honda Beat Fi, vol. 5, no. 2, 2018.

[4] M. D. Rahman, N. A. Wigraha, and G. Widayana, "Pengaruh Ukuran Katup Terhadap Torsi Dan Daya Pada Sepeda Motor Honda Supra Fit," J. Pendidik. Tek. Mesin Undiksha, vol. 5, no. 3, pp. 45-54, 2019, doi: 10.23887/jjtm.v5i3.20283.

[5] G. Aditya and D. Darlis, "PERANCANGAN DYNOTEST PORTABLE UNTUK SEPEDA MOTOR DENGAN SISTEM MONITORING MENGGUNAKAN MODUL ISM FREKUENSI 2. $4 \mathrm{GHz}$ DYNOTEST POTABLE DESIGN FOR MOTORCYCLE WITH MONITORING SYSTEM USING ISM MODULE FREQUENCY 2 . 4 GHZ," e-Proceeding Appl. Sci., vol. 1, no. 2, pp. 1231-1238, 2015.

[6] F. Wijayanti and D. Irwan, "Analisis Pengaruh Bentuk Permukaan Piston Terhadap Kinerja Motor Bensin,” J. Ilm. Tek. Mesin Unisma “45” Bekasi, vol. 2, no. 1, p. 98156, 2014.

[7] UMMI KULTSUM, "Studi Eksperimental Performa Yamaha Vixion 150 Menggunakan Magic Ring Dan Modifikasi Exhaust Manifold Dengan Variasi Perbandingan Diameter Outlet Diffuser Terhadap Diameter Inlet Diffuser 1,25, 1,40, dan 1,60," Stud. Eksp. Performa Yamaha Vixion 150 Menggunakan Magic Ring Dan Modif. Exhaust Manifold Dengan Variasi Perbandingan Diam. Outlet Diffus. Terhadap Diam. Inlet Diffus. 1,25, 1,40, dan 1,60, 2019, [Online]. Available: http://eprints.ums.ac.id/74743/12/NASKAH PUBLIKASI.pdf.

[8] K. D. A. N. Manufaktur, "Analisa numerik kekuatan piston pada motor bakar dengan variasi geometri."

[9] M. Bakeri, A. Syarief, and A. Kusairi, "Analisa Gas Buang Mesin Berteknologi Efi Dengan Bahan Bakar Premium,” Info Tek., vol. 13, no. 1, pp. 28-38, 2012.

[10] Y. R. Fauzi, "Pengaruh Penambahan Turbo Cyclone Aksial Terhadap Aliran Dan Performa Motor Bakar," Turbo J. Progr. Stud. Tek. Mesin, vol. 7, no. 1, pp. 25-31, 2018, doi: 10.24127/trb.v7i1.679.

[11] Irpan Setiawan and Wilarso, "ANALISIS PERBANDINGAN TEKANAN TIPE POMPA BAHAN BAKAR INJEKSI DAN TIPE BAHAN BAKAR MEKANIK," TEKNOSAINS J. Sains, Teknol. dan Inform., vol. 8, no. 1, 2021, doi: 10.37373/tekno.v8i1.73.

[12] Nurmiati et al., "ANALISA SISTEM KERJA ELECTRICAL FUEL INJECTION (EFI) PADA MOTOR HONDA CBR 150," Anal. Sist. KERJA Electr. FUEL Inject. PADA Mot. HONDA CBR 150, vol. 1, no. 1, pp. 36-47, 2019.

[13] Saharuna, "Perbandingan Konsumsi Bahan Bakar Sepeda Motor Sistem Konvensional dan Sistem EFI," J. Teknol., vol. 19, no. 1, pp. 34-42, 2017.

[14] Noorsakti Wahyudi, "STUDI EKSPERIMEN PENGARUH VARIASI PERUBAHAN SUDUT INJEKTOR PADA SYSTEM EFI TERHADAP PERFORMA MOTOR 4 LANGKAH," JEECAE, vol. 1, no. 1, 2016, doi: https://doi.org/10.32486/jeecae.v1i1. 
[15] A. D. Efendi, “Terhadap Sudut Spray Dan Pembakaran Bahan Bakar Yang,” vol. 2, pp. 39-48, 2019.

[16] W. Wilarso, T. Wibowo, B. Teguh, and M. Mujiarto, "Analysis of injector spring damage to determine maintenance management diesel engine at PLTD Ampenan," J. Phys. Conf. Ser., vol. 1402, no. 7, 2019, doi: 10.1088/1742-6596/1402/7/077043.

[17] M. F. Rozaqi, "Pengaruh Variasi Diameter Lubang Nozzle Terhadap Dimensi," vol. 2, pp. 1724, 2019. 